Article

\title{
Rapid and Positive Effect of Bicarbonate Addition on Growth and Photosynthetic Efficiency of the Green Microalgae Chlorella Sorokiniana (Chlorophyta, Trebouxiophyceae)
}

\author{
Giovanna Salbitani ${ }^{\dagger}$, Francesco Bolinesi ${ }^{\dagger}$, Mario Affuso, Federica Carraturo $₫$, Olga Mangoni \\ and Simona Carfagna *(D) \\ Dipartimento di Biologia, Università di Napoli Federico II, Via Cinthia 21, 80126 Napoli, Italy; \\ giovanna.salbitani@unina.it (G.S.); francesco.bolinesi@unina.it (F.B.); mario.affuso@unina.it (M.A.); \\ federica.carraturo@unina.it (F.C.); olga.mangoni@unina.it (O.M.) \\ * Correspondence: simona.carfagna@unina.it \\ + Both authors contributed equally to this work.
}

Received: 26 May 2020; Accepted: 27 June 2020; Published: 29 June 2020

\begin{abstract}
Bicarbonate ions are the primary source of inorganic carbon for autotrophic organisms living in aquatic environments. In the present study, we evaluated the short-term (hours) effects of sodium bicarbonate $\left(\mathrm{NaHCO}_{3}\right)$ addition on the growth and photosynthetic efficiency of the green algae Chlorella sorokiniana (211/8k). Bicarbonate was added to nonaxenic cultures at concentrations of 1,2 , and $3 \mathrm{~g} \mathrm{~L}^{-1}$ leading to a significant increase in biomass especially at the highest salt concentration $\left(3 \mathrm{~g} \mathrm{~L}^{-1}\right)$ and also showing a bactericidal and bacteriostatic effect that helped to keep a reduced microbial load in the algal culture. Furthermore, bicarbonate stimulated the increase in cellular content of chlorophyll $a$, improving the photosynthetic performance of cells. Since microalgae of genus Chlorella spp. show great industrial potential for the production of biofuels, nutraceuticals, cosmetics, health, and dietary supplements and the use of bicarbonate as a source of inorganic carbon led to short-term responses in Chlorella sorokiniana, this method represents a valid alternative not only to the insufflation of carbon dioxide for the intensive cultures but also for the production of potentially bioactive compounds in a short period.
\end{abstract}

Keywords: pigments; photosynthetic efficiency; intensive culture; bio-application; sustainability

\section{Introduction}

Research studies on microalgae have increased in the last decades due to the wide range of applications associated with these photosynthetic microorganisms that can be utilized as sources of biofuels, pharmaceuticals, cosmetics, health, and dietary supplements [1-6]. Microalgal photosynthesis is similar to that of higher plants, although characterized by a higher yield compared to terrestrial crops as it is more efficient in converting solar into chemical energy [7]. Due to their high growth rate, these organisms can be easily cultured in closed bioreactor systems reaching high biomass yields $[4,8]$. Since the microalgae cultivation does not compete with that of terrestrial plants thanks to different resources use, the cultivation and exploitation of microalgae biomass represent an excellent opportunity for the development of alternative compounds for different bio-applications. The biological carbon pump is a major component of the global carbon cycle, which regulates atmospheric $\mathrm{CO}_{2}$ levels and transfers both organic and inorganic carbon fixed by primary producers in terrestrial and aquatic ecosystems [9].

While terrestrial photosynthetic organisms utilize the atmospheric carbon dioxide $\left(\mathrm{CO}_{2}\right)$ as a source of inorganic carbon (Ci) into Calvin-Benson cycle directly [10], aquatic photosynthetic organisms are 
adapted to use bicarbonate ions as an inorganic carbon source [10-12] since the carbonate/bicarbonate system converts $\mathrm{CO}_{2}$ into carbonate $\left(\mathrm{CO}_{3}{ }^{2-}\right)$ and bicarbonate $\left(\mathrm{HCO}_{3^{-}}\right)$ions. For this reason, the total inorganic carbon or dissolved inorganic carbon (DIC) in the aquatic environment is considered as the sum of inorganic carbon species in a solution, and it varies from less than $20 \mu \mathrm{M}$, in acidic soft waters, to more than $5 \mathrm{M}$, in highly alkaline hard waters [13].

Both freshwater and marine microalgae are able to absorb $\mathrm{HCO}_{3}$ - from the external environment into the cell through active membrane pumps [14]. The bicarbonate transferred into the cytosol is then converted by carbonic anhydrase enzyme (EC: 4.2.1.1) in $\mathrm{CO}_{2}$ usable in chloroplasts by Rubisco (EC: 2.1.1.127) for the Calvin-Benson cycle to produce 3-phosphoglycerate $[15,16]$. Microalgae have developed a carbon concentrating mechanism (CCM) which pumps extracellular bicarbonate ions into cells and raises the intracellular levels of $\mathrm{CO}_{2}$, promoting the carboxylation reaction and suppressing the oxygenase reaction of Rubisco, as well as the photorespiration [16-18]. Zaho et al. [19] demonstrated that $\mathrm{HCO}_{3^{-}}$is also an important constituent of the water-oxidizing complex of photosystem II (PSII), by binding other components of PS II and influencing the molecular processes associated with the electron acceptor and electron donor sides of PS II.

Generally, insufflating pure $\mathrm{CO}_{2}$ in microalgae cultivation is a system used to obtain a high level of biomass, although this process could be expensive [20] and inefficient due to the loss of $\mathrm{CO}_{2}$ in the atmosphere [21]. For this reason, the use of sodium bicarbonate $\left(\mathrm{NaHCO}_{3}\right)$ as algal feedstock may be a cheaper and more sustainable alternative, considering its better solubility in aqueous solution than $\mathrm{CO}_{2}\left(9.21 \%(\mathrm{w} / \mathrm{w})\right.$ at $\left.25^{\circ} \mathrm{C}\right)[22,23]$. In the last years, several studies demonstrated that bicarbonate has a positive outcome on growth and metabolite accumulation as lipids, starch, and pigments in numerous microalgae $[15,22-29]$.

Chlorella spp. (Chlorophyta, Trebouxiophyceae) is a genus of green microalgae without flagella that shows spherical shape (ø 2 to $10 \mu \mathrm{m})$. Chlorella spp. has few and small vacuoles in the cytoplasm and a single and huge chloroplast in the shape of a cup with a starch granule. The chloroplast contains the green photosynthetic pigments chlorophyll-a and $-b, \beta$-carotene, and xanthophyll. Through photosynthesis, Chlorella multiplies rapidly, requiring only carbon dioxide, water, sunlight, and a small amount of minerals to reproduce.

Chlorella spp. (Chlorophyta, Trebouxiophyceae) are one of the most widely used microalgae in the industrial sector, with an annual production of about $2000 \mathrm{t}$ [1]. In the last decade, microalgae belonging to genus Chlorella have caught scientific attention for their ability to synthesize important nutritional compounds, such as essential amino acids, polyunsaturated fatty acids, carotene, and vitamins [30-32]. Microalgae have been consumed in the human diet for thousands of years, and Chlorella spp. represents one of the few species utilized as an effective supplementary food [30,33]. Several species of Chlorella have been extensively used commercially over the past 40 years as a food and feed supplement and nutraceuticals $[33,34]$. The interest in these species is due to their high productivity, high lipid content, and resistance to the high light conditions typical of photobioreactors [34,35].

Recently, several studies on Chlorella spp. focused on the impact of $\mathrm{CO}_{2}$-gas, rather than bicarbonate, on growth and metabolites of these species [15,21,33,35-37]. Nevertheless, to date, no research has deepened the short-term (hours) physiologic and metabolic effects of bicarbonate addition on this genus. The main object of this study is to evaluate the immediate effects of bicarbonate additions on both growth and photosynthetic efficiency of the green microalga Chlorella sorokiniana (211/8k) cultivated in a nonaxenic culture under different bicarbonate concentrations.

\section{Materials and Methods}

\subsection{Algal Strains and Growth Conditions}

Chlorella sorokiniana Shihira and Krauss, strain 211/8k (CCAP of Cambridge University) was grown in a batch cultured at $32 \pm 2.5^{\circ} \mathrm{C}$, under continuously light (LED in red and blue spectra, $200 \mu \mathrm{mol}$ photons $\mathrm{m}^{-2} \mathrm{~s}^{-1}$ ) with no $\mathrm{CO}_{2}$ insufflation except that normally present in the flushed air. 
The basal medium ( $\mathrm{pH}$ 6.5) reported by Salbitani and colleagues [38] had the following composition: $13 \mathrm{mM} \mathrm{KH}_{2} \mathrm{PO}_{4}, 4.3 \mathrm{mM} \mathrm{K}_{2} \mathrm{HPO}_{4}, 0.35 \mathrm{mM} \mathrm{NaCl}, 1.2 \mathrm{mM} \mathrm{MgSO}_{4}, 0.35 \mu \mathrm{M}$ Fe-EDTA, $0.18 \mathrm{mM} \mathrm{CaCl}_{2}$, $5 \mathrm{mM} \mathrm{KNO}_{3}$, oligo-elements $(0.31 \mu \mathrm{M} \mathrm{Cu}, 0.1 \mu \mathrm{M} \mathrm{Mo}, 9.1 \mu \mathrm{M} \mathrm{Mn}, 0.76 \mu \mathrm{M} \mathrm{Zn}, 46 \mu \mathrm{M}$ B). Cultures of C. sorokiniana were grown at different concentrations of $\mathrm{NaHCO}_{3}\left(0,1,2,3 \mathrm{~g} \mathrm{~L}^{-1}\right)$, added in a single administration at $\mathrm{T} 0$, when cultures were into the lag phase $\left(\sim 2.5 \times 10^{6}\right.$ cell $\left.\mathrm{mL}^{-1}\right)$. All treatments were monitored daily, and the growth was evaluated spectrophotometrically by measuring optical density (OD) at $800 \mathrm{~nm}$. The cell number and average cell diameter (cellular size) were determined by a Countess II FL Automated Cell Counter (Thermo Fisher Scientific).

The growth rate was calculated using the following formula: $\mu=1 / t\left(\operatorname{lnN}_{2} \ln N_{1}\right)$, where $t$ is the time (days) of observation, $\mathrm{N}_{2}$ is the cell concentration (cell $\mathrm{mL}^{-1}$ ) at the beginning of the experiment period $(0 \mathrm{~h})$, and $\mathrm{N}_{1}$ is the cell concentration at the end of the experiment period $(72 \mathrm{~h})$. The doubling time or time required to achieve a doubling of the number of viable cells was calculated according to the following equation: $\mu=\ln 2 / t_{d}$, where: $\mu$ is the growth rate, $t_{d}$ is the doubling time.

\subsection{Pigment Contents}

To evaluate the effects of bicarbonate additions on chlorophyll $a$ (Chl-a) and phaeopigments (Phaeo) concentration at different treatments, $2 \mathrm{~mL}$ of culture were filtered through Whatman GF/F filters ( $25 \mathrm{~mm}$ diameter) and spectrofluorometric analyses were made within a maximum of $12 \mathrm{~h}$ after collection using a Shimadzu spectrofluorometer [39]. The instrument was calibrated and checked with a solution of Chl- $a$ extracted from spinach (Sigma). In addition, to contribute to the definition of the pigments' composition of different treatments, in terms of ratios pigment:Chl- $a$, an HPLC analysis has been performed at time 0 and at the end of the experiment (Supplementary Materials, Table S2). To this aim, $10 \mathrm{~mL}$ of culture were filtered onto Whatman GF/F filters ( $47 \mathrm{~mm}$ diameter) and stored at $-80^{\circ} \mathrm{C}$ until the HPLC analysis was performed [40]. Pigments' separations were made on an Agilent 1100 HPLC according to the method outlined in Vidussi et al. [41], as modified by Brunet and Mangoni [42]. The system was equipped with an HP 1050 photodiode array detector.

\subsection{Photosynthetic Efficiency}

The maximum PSII photochemical efficiency (Fv/Fm) and the maximum PSII effective absorption cross-section ( $\sigma \mathrm{PSII})$, which describes the functional 'target area' of the light-harvesting antenna that is energetically coupled to the $\mathrm{O}_{2}$-evolving reaction centers (RCIIs) ( $\left.\sigma \mathrm{PSII}\right)[43,44]$, have been determined using a Phyto_PAM II compact unit (Walz) [45]. All samples were acclimated in the dark for $30 \mathrm{~min}$ before the analysis to minimize the nonphotochemical dissipation of excitation, and measurements were blank corrected using the culture media without cells [46]. As regards Fv/Fm, samples were illuminated with a saturating pulse, according to Maxwell and Jonson [47], and values derived from the formula $\mathrm{Fv} / \mathrm{Fm}=(\mathrm{Fm}-\mathrm{F} 0) / \mathrm{Fm}$. For the determination of $\sigma \mathrm{PSII}$ at $440 \mathrm{~nm}$, we used the fast kinetics windows (Phyto Win_3 software) for the analysis of the wavelength-dependent O-I1 fluorescence rise kinetics upon onset of pulses of strong actinic light. All samples were far-red pre-illuminated before the analysis to inhibit the PS I response [48].

\subsection{Evaluation of Microbial Load Reduction}

Aliquots from control and sodium bicarbonate $\left(\mathrm{NaHCO}_{3} 3 \mathrm{~g} \mathrm{~L}^{-1}\right)$ added cultures were collected and underwent microbiological analysis to determine the total bacterial load. The microbial load was evaluated employing the spread plating method on agarized growth medium. In aseptic conditions, aliquots of $100 \mu \mathrm{L}$ were collected at 3 different times: 0,3 , and $48 \mathrm{~h}$. Specimens were transferred in $90 \mathrm{~mm}$ Petri dishes containing Plate Count Agar (Plate Count Agar-Thermo Scientific) using a sterile spatula. Samples were serially diluted, and serial decimal dilutions were spread-plated on Plate Count Agar dishes (UNI EN ISO 7218:2013, [49]). Plates were incubated in aerobic conditions at $30 \pm 2.5^{\circ} \mathrm{C}$ for $72 \mathrm{~h}$. Analyses were performed in triplicate. Results were expressed by reporting colony-forming units $\mathrm{mL}^{-1}\left(\mathrm{CFU} \mathrm{mL}{ }^{-1}\right)$ grown in each sample, considering the performed dilutions [50]. 


\subsection{Statistical Analysis}

The statistical analysis was performed by one-way analysis of variance (ANOVA) with a Tukey post-hoc test to determine differences between experimental cultures. To define in detail the relationship among all considered variables over the entire duration of the experiment, we performed a multivariate analysis (principal component analysis (PCA) and Biplot graph) using XLSTAT 2019 software. Data for the mean \pm standard deviation of 3-5 independent experiments are presented.

\section{Results}

\subsection{Impact of Sodium Bicarbonate Supplementation on Chlorella Growth}

The growth of Chlorella sorokiniana was monitored for $72 \mathrm{~h}$ as changes in optical density $\left(\mathrm{OD}_{800}\right)$, cell number, and cellular size. The addition of sodium bicarbonate $\left(\mathrm{NaHCO}_{3}\right)$ as 1,2 , and $3 \mathrm{~g} \mathrm{~L}^{-1}$, occurred in a single administration at T0 (lag phase). At T0 the number of cells for each culture treatment was about $2.5 \times 10^{6}$ cell mL $\mathrm{mL}^{-1}$ so that the administration of a different amount of $\mathrm{NaHCO}_{3}$ $\left(1,2\right.$, and $\left.3 \mathrm{~g} \mathrm{~L}^{-1}\right)$ corresponded to $0.4,0.8,1.2 \mathrm{ng} \mathrm{NaHCO}_{3}$ cell $^{-1}$, respectively.

Based on the optical density (Figure 1), during the first three hours, no significant change was observed among experimental conditions. After $24 \mathrm{~h}$, the treatment $\mathrm{NaHCO}_{3} 3 \mathrm{~g} \mathrm{~L}^{-1}$ showed the highest growth. After $48 \mathrm{~h}$, treatments 2 and $3 \mathrm{NaHCO}_{3} \mathrm{~g} \mathrm{~L}^{-1}$ showed a significant increase in biomass compared to the control. However, at $72 \mathrm{~h}$, both 1 and $2 \mathrm{~g} \mathrm{~L}^{-1}$ treatments displayed even a significantly lower OD as the control, while $3 \mathrm{~g} \mathrm{~L}^{-1}$ treatment showed a value similar to that of control cells.

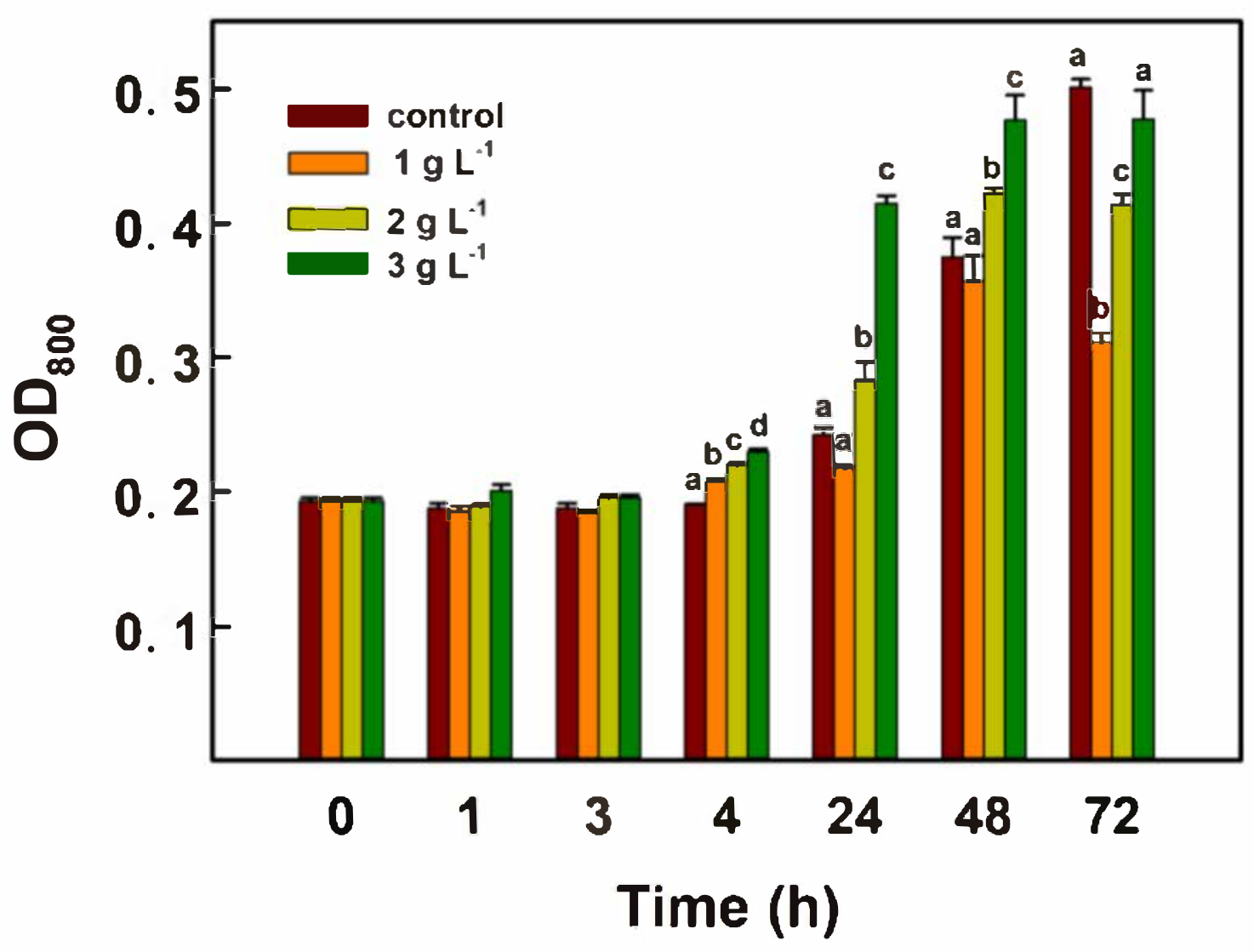

Figure 1. Chlorella sorokiniana growth determined by optical density $\left(\mathrm{OD}_{800}\right)$ estimation in control cells and after different bicarbonate addition $\mathrm{NaHCO}_{3} 1 \mathrm{~g} \mathrm{~L}^{-1}, 2 \mathrm{~g} \mathrm{~L}^{-1}$, and $3 \mathrm{~g} \mathrm{~L}^{-1}$. Error bars represent SD $(n=3)$. The values with the same letter were not significantly different $(p \leq 0.001$, ANOVA, Tukey's multiple comparison). 
In terms of the number of cells (Figure 2), no significant differences emerged in the first $4 \mathrm{~h}$. After $24 \mathrm{~h}$, the control showed the highest number of cells with a strong difference with other treatments, among which $\mathrm{NaHCO}_{3} 3 \mathrm{~g} \mathrm{~L}^{-1}$ displayed higher values. After $48 \mathrm{~h}$, the control was still characterized by the highest number of cells, but $\mathrm{NaHCO}_{3} 3 \mathrm{~g} \mathrm{~L}^{-1}$ showed a net increase with a value similar to that of the control. Treatments 1 and $2 \mathrm{~g} \mathrm{~L}^{-1}$ presented a lower number of cells, with $1 \mathrm{~g} \mathrm{~L}^{-1}$ being the lowest. At the end of the experiment, the treatment with the highest number of cells was $3 \mathrm{~g} \mathrm{~L}^{-1}$ that exceeded the control. As regards $1 \mathrm{~g} \mathrm{~L}^{-1}$ and $2 \mathrm{~g} \mathrm{~L}^{-1}$, both displayed the same pattern observed at $48 \mathrm{~h}$, with $2 \mathrm{~g} \mathrm{~L}^{-1}$ characterized by a higher number of cells. The difference in the average cells' size is shown in Figure 3. Already after $1 \mathrm{~h}$ from $\mathrm{NaHCO}_{3}$ addition, the size of cells supplemented with $3 \mathrm{~g} \mathrm{~L}^{-1}$ appeared larger $(3.0 \pm 0.03 \mu \mathrm{m})$ with respect to control $(2.4 \pm 0.3 \mu \mathrm{m})$ and to the other conditions. Until $24 \mathrm{~h}$, the cells added with $\mathrm{NaHCO}_{3} 3 \mathrm{~g} \mathrm{~L}^{-1}$ showed a larger diameter than the cells of the other conditions. From 48 to $72 \mathrm{~h}$, the cells of the other two experimental conditions $\left(\mathrm{NaHCO}_{3} 1\right.$ and $2 \mathrm{~g} \mathrm{~L}^{-1}$ ) also increased their diameter compared to the control (Figure 3). In Table S1, the data concerning the variations of growth rate and doubling time in the control cells and in the experimental cultures are shown.

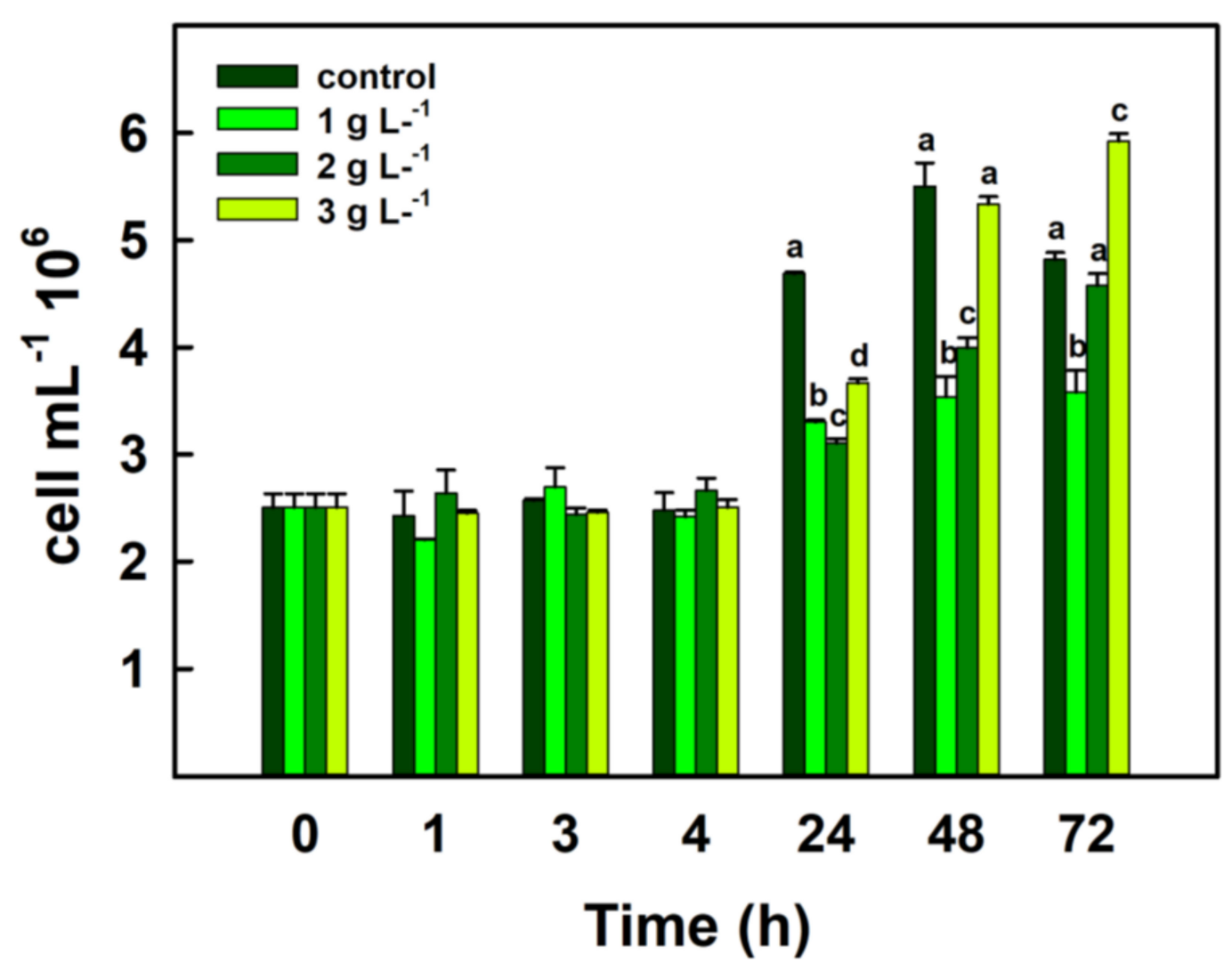

Figure 2. Cellular density (cells $\mathrm{mL}^{-1}$ ) in Chlorella sorokiniana control and bicarbonate enriched cultures $\left(\mathrm{NaHCO}_{3} 1 \mathrm{~g} \mathrm{~L}^{-1}, 2 \mathrm{~g} \mathrm{~L}^{-1}\right.$, and $\left.3 \mathrm{~g} \mathrm{~L}^{-1}\right)$. Error bars represent $\mathrm{SD}(n=3)$. The values with the same letter were not significantly different ( $p \leq 0.001$, ANOVA, Tukey's multiple comparison). 


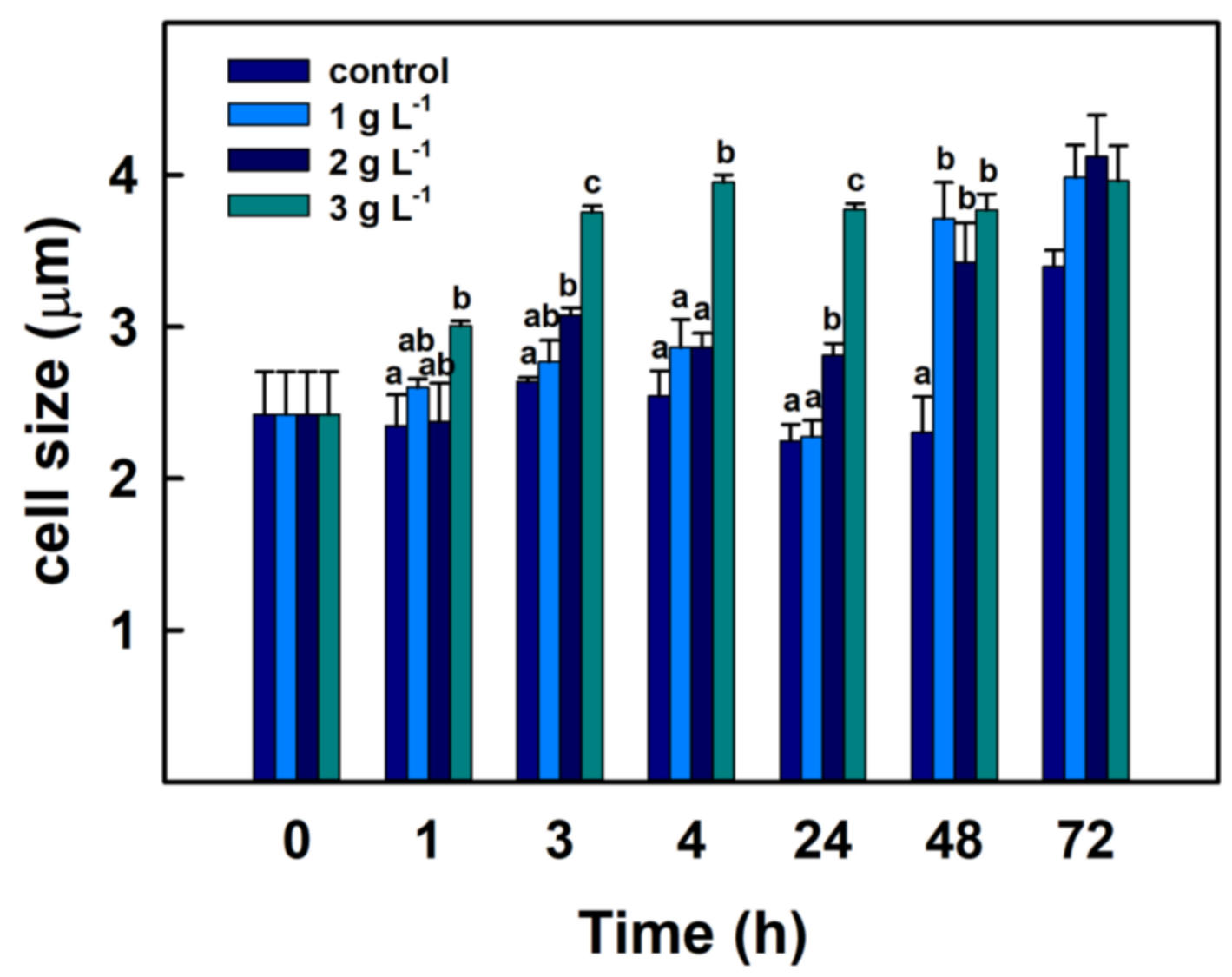

Figure 3. Average cell diameter of Chlorella sorokiniana control and bicarbonate enriched cultures cells $\left(\mathrm{NaHCO}_{3} 1 \mathrm{~g} \mathrm{~L}^{-1}, 2 \mathrm{~g} \mathrm{~L}^{-1}\right.$, and $\left.3 \mathrm{~g} \mathrm{~L}^{-1}\right)$. Error bars represent $\mathrm{SD}(n=3)$. The values with the same letter were not significantly different ( $p \leq 0.001$, ANOVA, Tukey's multiple comparison).

\subsection{Impact of Sodium Bicarbonate Supplementation on Pigments}

The chlorophyll $a$ (Chl-a) content per cell was determined during $72 \mathrm{~h}$ of the experiment in each treatment (Figure 4). While the control did not show any increase in Chl- $a$ for the overall duration of the experiment, the amount of Chl- $a$ in other treatments increased up to $50 \%-65 \%$ after $1 \mathrm{~h}$ later from the $\mathrm{NaHCO}_{3}$ administration, remaining high until $4 \mathrm{~h}$. After $24 \mathrm{~h}$, the Chl- $a$ content was different among the treatments. $\mathrm{NaHCO}_{3} 2 \mathrm{~g} \mathrm{~L}^{-1}$ and $\mathrm{NaHCO}_{3} 3 \mathrm{~g} \mathrm{~L}^{-1}$ showed the highest values of Chl- $a$, almost two times more than $\mathrm{NaHCO}_{3} 1 \mathrm{~g} \mathrm{~L}^{-1}$. At $72 \mathrm{~h}$, in the culture enriched with $\mathrm{NaHCO}_{3} 3 \mathrm{~g} \mathrm{~L}^{-1}$,

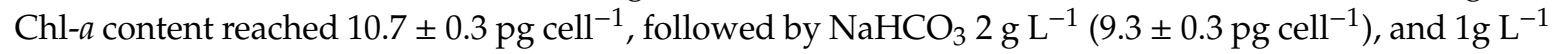
$\left(3.7 \pm 0.3 \mathrm{pg} \mathrm{cell}^{-1}\right)$. The Phaeo/Chl- $a$ ratio (Table 1$)$, calculated as a proxy of active chlorophyll [51,52], remained constant $(\sim 1)$ in the control treatment for the entire duration of the experiment $(72 \mathrm{~h})$. In bicarbonate treatments, the ratio Phaeo/Chl- $a$ slightly increased after $3 \mathrm{~h}$, then values tended to decrease, showing a weak difference between the control and $\mathrm{NaHCO}_{3}\left(2\right.$ and $\left.3 \mathrm{~g} \mathrm{~L}^{-1}\right)$ supplemented after $72 \mathrm{~h}$. Further details on the effect of bicarbonate addition on the concentration of other photosynthetic pigments have been reported in the Supplementary Materials (Table S2) as pigment:Chl- $a$ ratios. Although additional analyses are required, these preliminary data seem to suggest that the lutein:Chl- $a$ ratio slightly increased in bicarbonate treated cells, particularly those supplemented with $3 \mathrm{~g} \mathrm{~L}^{-1}$. A typical chromatogram of photosynthetic pigments extracted in Chlorella sorokiniana cells is shown in the Supplemental Material (Figure S1). 


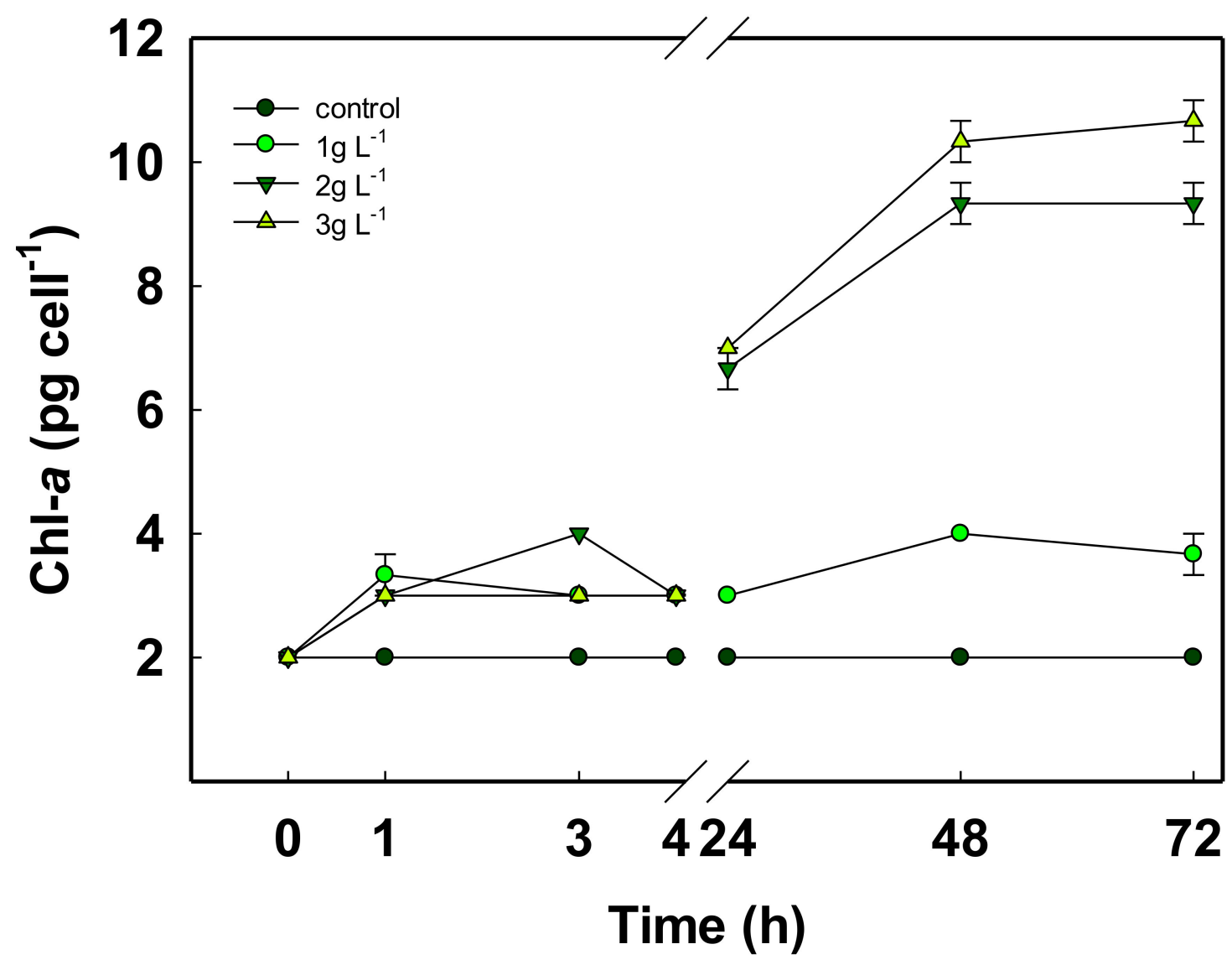

Figure 4. Chlorophyll $a$ content in Chlorella sorokiniana control and in bicarbonate enriched cultures cells $\left(\mathrm{NaHCO}_{3} 1 \mathrm{~g} \mathrm{~L}^{-1}, 2 \mathrm{~g} \mathrm{~L}^{-1}\right.$, and $\left.3 \mathrm{~g} \mathrm{~L}^{-1}\right)$. Error bars represent $\mathrm{SD}(\mathrm{n}=3)$.

Table 1. Time course of changes in phaeopigments vs. chlorophyll $a$ ratio ([Phaeo]/[Chl- $a]$ ) in control and in sodium bicarbonate enriched cultures. Values are means $(n=3) \pm$ standard deviation. The superscript letters indicate the statistical significance: identical letters identify means that are not significantly different; different letters identify statistically different means $(p \leq 0.001)$. Upper case letters indicate the comparison between the experimental conditions (control, 1, 2, and $3 \mathrm{~g} \mathrm{~L}^{-1}$ ).

\begin{tabular}{cccccccc}
\hline \multicolumn{7}{c}{ Time (h) } \\
\hline & $\mathbf{0}$ & $\mathbf{1}$ & $\mathbf{3}$ & $\mathbf{4}$ & $\mathbf{2 4}$ & $\mathbf{4 8}$ & $\mathbf{7 2}$ \\
\hline Control & $0.99 \pm 0.08^{\mathrm{Aa}}$ & $1.01 \pm 0.01^{\mathrm{Aa}}$ & $1.00 \pm 0.02^{\mathrm{Aa}}$ & $1.02 \pm 0.05^{\mathrm{Aa}}$ & $0.96 \pm 0.06^{\mathrm{Aa}}$ & $0.97 \pm 0.02^{\mathrm{Aa}}$ & $1.00 \pm 0.04^{\mathrm{Aa}}$ \\
\hline $1 \mathrm{~g} \mathrm{~L}^{-1}$ & $1.00 \pm 0.01^{\mathrm{Aa}}$ & $0.98 \pm 0.07^{\mathrm{Aa}}$ & $1.31 \pm 0.07^{\mathrm{Bb}}$ & $0.94 \pm 0.03^{\mathrm{Aa}}$ & $0.83 \pm 0.07^{\mathrm{Cc}}$ & $0.88 \pm 0.03^{\mathrm{Aab}}$ & $0.98 \pm 0.02^{\mathrm{Aa}}$ \\
\hline $2 \mathrm{~g} \mathrm{~L}^{-1}$ & $0.99 \pm 0.07^{\mathrm{Aa}}$ & $1.04 \pm 0.04^{\mathrm{Aa}}$ & $1.28 \pm 0.08^{\mathrm{Bb}}$ & $0.96 \pm 0.04^{\mathrm{Aa}}$ & $0.81 \pm 0.08^{\mathrm{Cac}}$ & $0.79 \pm 0.02^{\mathrm{Cc}}$ & $0.90 \pm 0.05^{\mathrm{Cc}}$ \\
\hline $3 \mathrm{~g} \mathrm{~L}^{-1}$ & $0.99 \pm 0.08^{\mathrm{Aa}}$ & $0.99 \pm 0.02^{\mathrm{Aa}}$ & $1.22 \pm 0.06^{\mathrm{Bb}}$ & $1.00 \pm 0.02^{\mathrm{Aa}}$ & $0.63 \pm 0.02^{\mathrm{Dd}}$ & $0.76 \pm 0.01^{\mathrm{Cc}}$ & $0.78 \pm 0.02^{\mathrm{Cc}}$ \\
\hline
\end{tabular}

\subsection{Impact of Sodium Bicarbonate Supplementation on Pigments Photosystem II Efficiency}

The maximum quantum yield $[\mathrm{Fv} / \mathrm{Fm}=(\mathrm{Fm}-\mathrm{F} 0) / \mathrm{Fm}]$ increased over $24 \mathrm{~h}$ for all treatments (Figure 5). In the first $4 \mathrm{~h}, \mathrm{Fv} / \mathrm{Fm}$ changed from 0.2 to $0.32 \pm 0.027$ in $1 \mathrm{~g} \mathrm{~L}^{-1}$, to $0.36 \pm 0.024$ in $2 \mathrm{~g} \mathrm{~L}^{-1}$ and to $0.37 \pm 0.024$ in $3 \mathrm{~g} \mathrm{~L}^{-1}$ supplemented, while the control slightly increased up to $0.24 \pm 0.014$ (Figure 5). After $24 \mathrm{~h}$, algal cells supplemented with bicarbonate reached their maximum Fv/Fm values but later, while $\mathrm{NaHCO}_{3} 3 \mathrm{~g} \mathrm{~L}^{-1}$ remained high until the end of the experiments, $\mathrm{NaHCO}_{3} 1 \mathrm{~g} \mathrm{~L}^{-1}$ and $2 \mathrm{~g} \mathrm{~L}^{-1}$ both decreased to the values of about 0.32 . Control cells, instead, showed lower Fv/Fm for the entire period, reaching a relative maximum of $0.28 \pm 0.012$ after $72 \mathrm{~h}$. The maximum PSII effective absorption cross-section ( $\sigma$ PSII) of the control cells differed significantly from bicarbonate treatments after $72 \mathrm{~h}$ (Figure 6). While in the first $2 \mathrm{~h}, \sigma \mathrm{PSII}$ of $\mathrm{NaHCO}_{3} 1,2,3 \mathrm{~g} \mathrm{~L}^{-1}$ supplemented cells were 
similar to that observed in the control, after $4 \mathrm{~h} \mathrm{NaHCO}_{3} 2$ and $3 \mathrm{~g} \mathrm{~L}^{-1}$ supplemented cells showed a sensible decrease to $4.88 \pm 0.06$ and $3.57 \pm 0.05$, respectively. After $24 \mathrm{~h}$, bicarbonate treated cells displayed a visible and significant difference in $\sigma$ PSII compared to the control $(6.57 \pm 0.11)$.

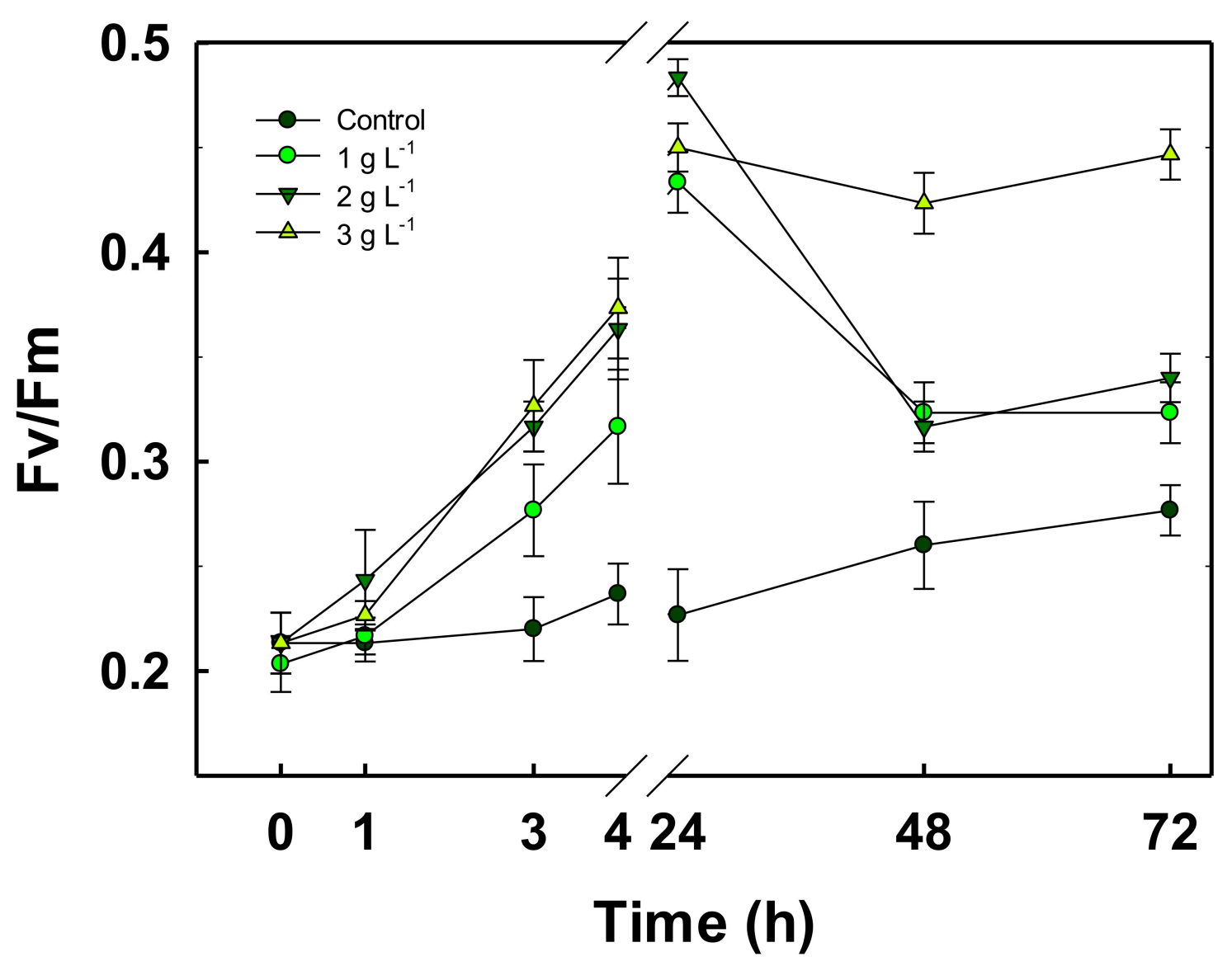

Figure 5. Maximum quantum yield (Fv/Fm) in Chlorella sorokiniana control cells and in bicarbonate $1 \mathrm{~g} \mathrm{~L}^{-1}, 2 \mathrm{~g} \mathrm{~L}^{-1}$, and $3 \mathrm{~g} \mathrm{~L}^{-1}$ enriched cultures. Error bars represent $\mathrm{SD}(\mathrm{n}=3)$. 


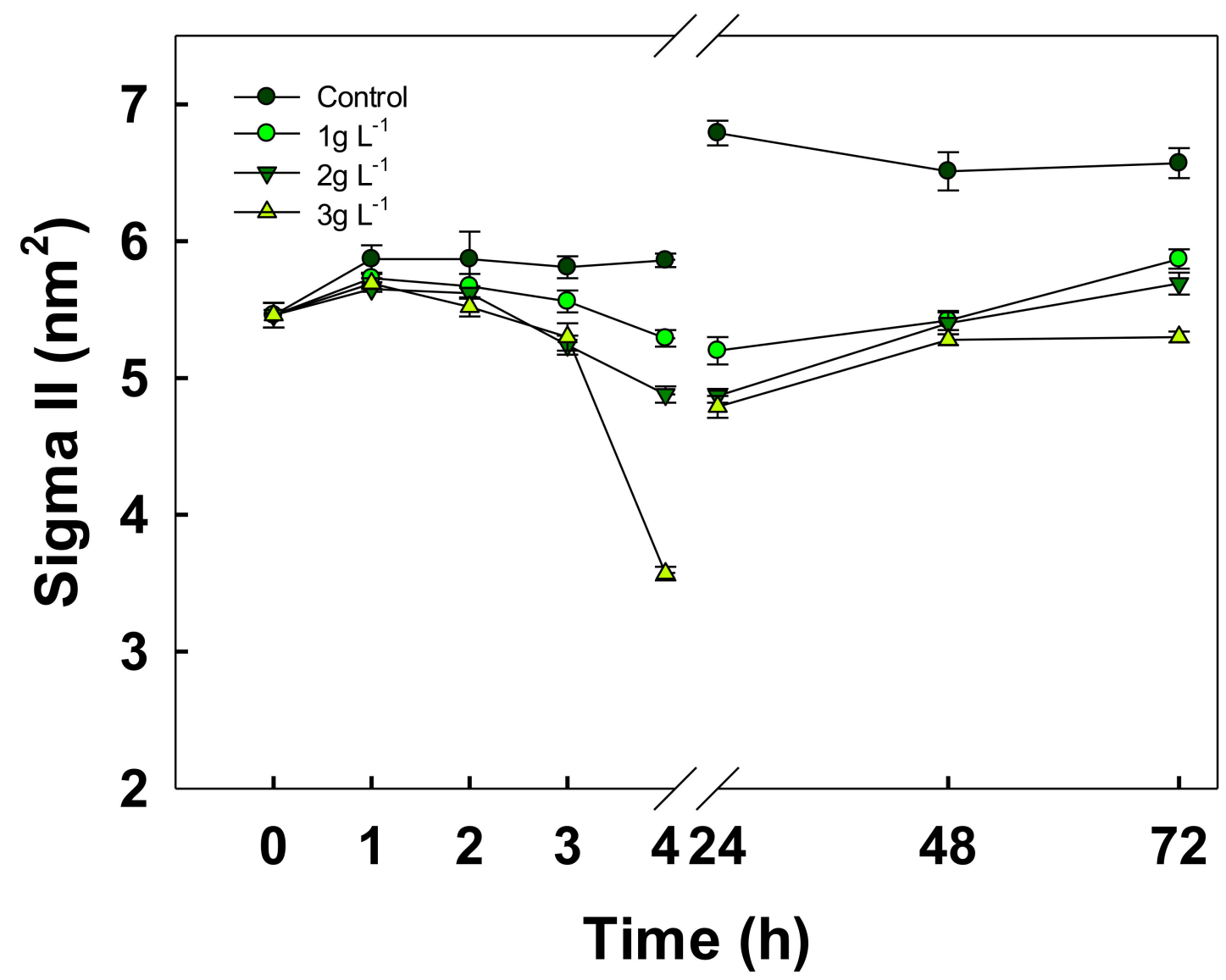

Figure 6. Maximum photosystem II (PSII) effective absorption $(440 \mathrm{~nm})$ cross-section $(\sigma \mathrm{PSII})$ in Chlorella sorokiniana control cells and in cells grown in bicarbonate $1 \mathrm{~g} \mathrm{~L}^{-1}, 2 \mathrm{~g} \mathrm{~L}^{-1}$, and $3 \mathrm{~g} \mathrm{~L}^{-1}$ enriched medium. Error bars represent SD $(n=3)$.

\subsection{Evaluation of Microbial Load Reduction}

Data concerning the evaluation of microbial load in the control and $3 \mathrm{~g} \mathrm{~L}^{-1}$ bicarbonate added cultures are reported in Figure 7. Starting from an initial concentration of $\sim 3.0 \times 10^{6} \mathrm{UFC} / \mathrm{mL}$ microbial load, samples containing $\mathrm{NaHCO}_{3}$ presented a reduced microorganisms concentration compared to control cultures after $3 \mathrm{~h}$, showing 1 log decrease from $3.0 \times 10^{6} \mathrm{CFU} \mathrm{mL}^{-1}$, to $3.02 \times 10^{5} \mathrm{CFU} \mathrm{mL}^{-1}$. After $48 \mathrm{~h}$, a $34.21 \%$ microbial load increase was observed in control, while an $11.62 \%$ growth was evidenced in $\mathrm{NaHCO}_{3}$ samples. 


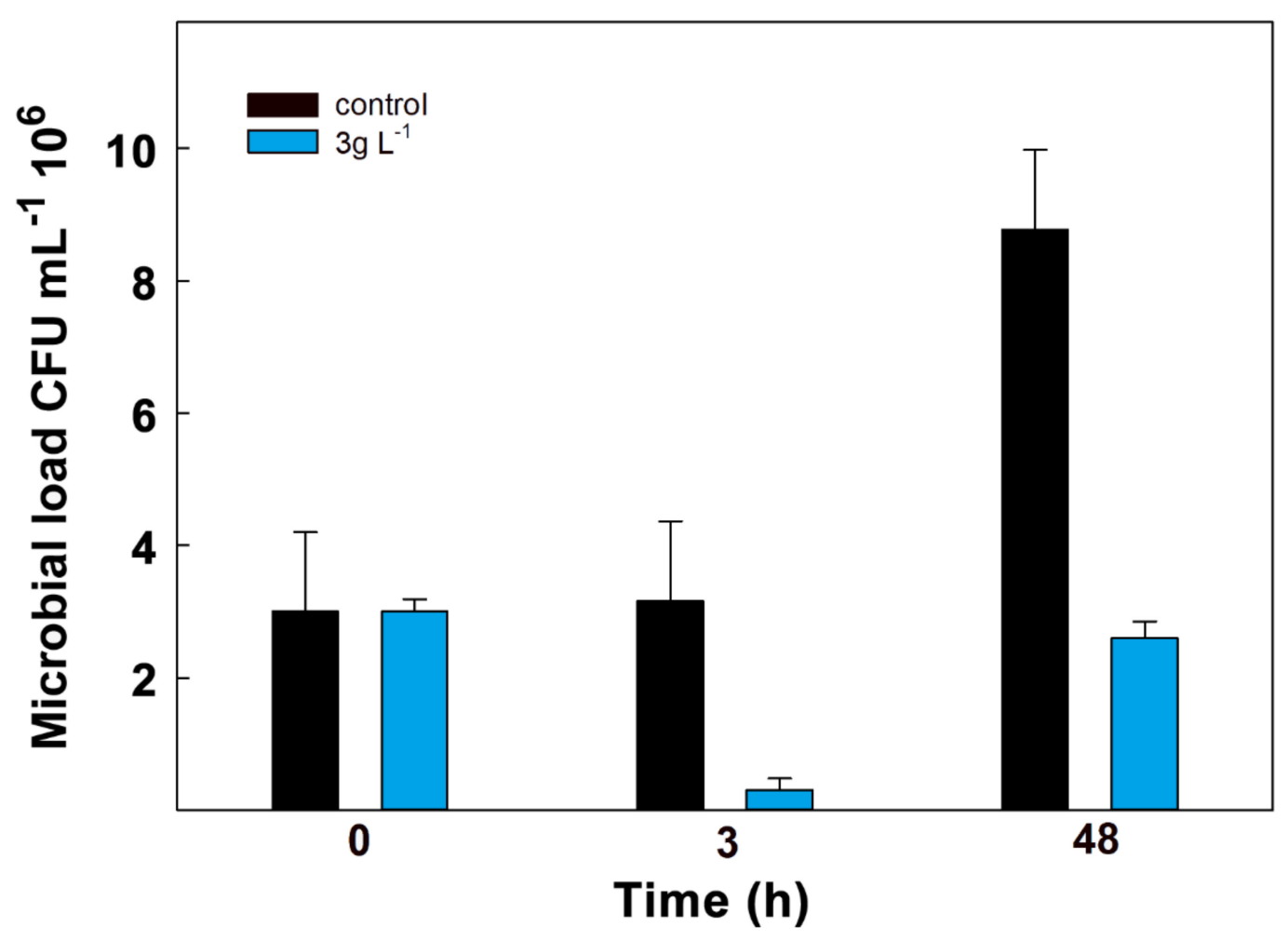

Figure 7. Microbial contamination reduction in Chlorella sorokiniana cultured with 0 or $3 \mathrm{~g} \mathrm{~L}^{-1}$ of sodium bicarbonate. Analysis performed three times, after 0,3 , and $48 \mathrm{~h}$ after bicarbonate addition.

\subsection{Statistical Analysis}

The results obtained using a PCA explained $78.19 \%$ of the total variance, with the F1 axis accounting for $53.10 \%$ and the F2 axis for $25.09 \%$ of the total variance (Figure 8). All variables were positively correlated with the positive F1 axis except the ratio Phaeo/Chl- $a$ and, to a lesser extent, $\sigma \mathrm{PSII}$ that was negatively correlated with $\mathrm{F} 1$. Cell $\mathrm{mL}^{-1}$, time, and OD variables were positioned in the first quadrant, while Chl- $a$, cell size, Fv/Fm, and Treatment showed a negative correlation with F2 axis, being positioned in the second quadrant. The Phaeo/Chl- $a$ ratio was instead positioned in the third quadrant, almost overlapping the negative F2 axis, while $\sigma$ PSII was positioned in the fourth quadrant with a higher correlation with the positive F2 axis. To investigate the influence of bicarbonate addition on the considered variables, we performed a PCA, coloring the observation by treatment, with ellipses of confidence of $95 \%$. The light blue point and line represent the $1 \mathrm{~g} \mathrm{~L}^{-1}$ treatment; the yellow color represents $2 \mathrm{~g} \mathrm{~L}^{-1}$ treatment, the purple $3 \mathrm{~g} \mathrm{~L}^{-1}$ treatment, and the dark blue the control one. The biplot graph shows clear differences between the control and all bicarbonate treatments, with ellipses highlighting the effect of bicarbonate addition already at low concentrations and control treatment, clearly different from others. Moreover, the amplitude of the ellipses increased with bicarbonate addition. 


\section{Observations (axes F1 and F2: 78,19\%)}

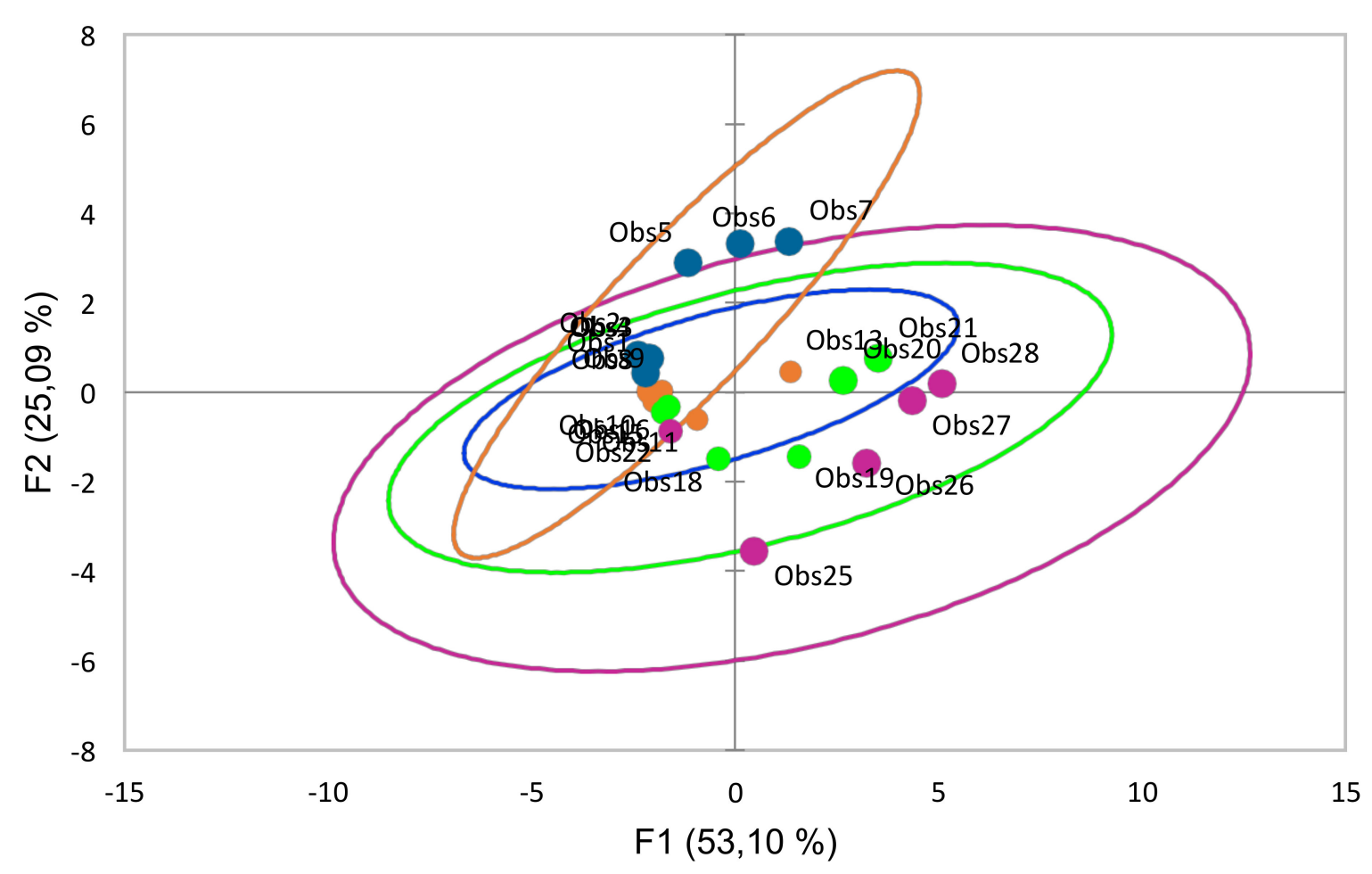

\section{$1 \mathrm{~g} / \mathrm{L} \odot 2 \mathrm{~g} / \mathrm{L} \bullet 3 \mathrm{~g} / \mathrm{L} \bullet \mathrm{CTRL}$}

Figure 8. Principal component analysis (PCA): Distribution of treatments grouped according to different bicarbonate concentration. Control (orange color), $1 \mathrm{~g} \mathrm{~L}^{-1}$ (blue color), $2 \mathrm{~g} \mathrm{~L}^{-1}$ (green color), and $3 \mathrm{~g}$ $\mathrm{L}^{-1}$ (pink color).

\section{Discussion}

Despite the wide range of applications, microalgal production is not economically viable yet. Several research pathways have been explored to improve the economics of the process [53]. Among these, recent studies on the effects of bicarbonate in microalgae cultivation aimed to improve biomass production or content of functional molecules $[23,26,28,29]$. The bicarbonate salt, as an extra source of inorganic carbon for microalgal cultures, has been proposed due to the possibility of being produced by hydration of $\mathrm{CO}_{2}$ present in polluting fumes, reducing $\mathrm{CO}_{2}$ emissions into the atmosphere, besides economic advantages [27,54-56].

According to Peng and colleagues [57], appropriate concentrations of $\mathrm{NaHCO}_{3}$ caused the decline of protozoa in cultures, perhaps due to the water efflux affected by rose osmotic pressure. In this study, we focused attention on the short-term physiological and metabolic alterations occurring in algal cells after bicarbonate addition in Chlorella sorokiniana cells.

According to our data, after $24 \mathrm{~h}$, cultures supplemented with bicarbonate showed a clear increase in the optical density compared to the control. However, the OD increase was not accompanied by an increase in the number of cells. Interestingly, an increase in the cells' diameter in bicarbonate treated cells, even 50-60\% higher after $48 \mathrm{~h}$, was observed. This increase in cell diameter size probably could be related to starch or lipid accumulation as cellular carbon storage. In fact, in microalgae, Ci availability represents an important metabolic regulator that controls the carbohydrate and lipid synthesis [25]. According to some studies, lipid accumulation and a larger cellular diameter correlate with a decreased growth $[35,58]$. In fact, in some microalgae, bicarbonate addition induced a change in metabolism, 
shifting the cell from a growth state to a carbon-containing-product formation [24]. Cellular replication considerably stopped at the time of bicarbonate addition in Chlorella vulgaris [36].

However, the addition of bicarbonate has not always brought positive effects in microalgae cultures, especially in freshwater species [54]. In fact, adding bicarbonate leads to $\mathrm{Na}^{+}$ions rise in the growth medium, and although marine species tolerate them, most freshwater ones do not $[54,59]$. In Chlorella vulgaris, a supply of a high concentration of bicarbonate $(160 \mathrm{mM})$ inhibited cell growth leading to the formation of numerous colonial cells [35]. Furthermore, according to de Farias Silva et al. [22], in Synechococcus sp., an excess of $\mathrm{NaHCO}_{3}$ caused salt stress, ROS (reactive oxygen species) production, and a decrease in photosynthetic efficiency caused by damage to PSII complex. Our data, however, did not indicate any damage to Chlorella sorokiniana cells treated with bicarbonate, suggesting that the concentrations we used were under the threshold of tolerability.

In Chlorella sorokiniana, the addition of bicarbonate led to an increase in Chl-a for the entire duration of the experiment, with the highest values in cells supplemented with $\mathrm{NaHCO}_{3} 3 \mathrm{~g} \mathrm{~L}^{-1}$. The increase in Chl- $a$ contents per cell in the experimental cultures may be due to the greater availability of inorganic carbon in the growth medium that supports synthesizing the pigment. Since chlorophyll contents represent a valid indicator of the physiological status in microalgae [26,37], the high levels found in bicarbonate treatments are a signal of good cell health. Moreover, the lower Phaeo:Chl- $a$ ratio in the $\mathrm{NaHCO}_{3} 3 \mathrm{~g} \mathrm{~L}^{-1}$ treatment between 24 and $72 \mathrm{~h}$ indicates a greater presence of active chlorophyll compared to the control. Since in plant cells, the amount of phaeopigments usually increases with abiotic stress ( $\mathrm{pH}$, temperature, etc.) or with increasing age [60-62], we can deduce that the addition of bicarbonate at the used concentrations did not prejudice the photosynthetic performance of the algal cells. The capability of active fluorescence for rapidly assessing the photosynthetic physiology of phytoplankton live species has been well demonstrated by many studies [63-65]. Conceptually, the fluorescence measurements of the active chlorophyll $a$ evaluate the efficiency by which absorbed light is utilized by photosynthesis [66]. In this study, the maximum photosynthetic efficiency of photosystem II (Fv/Fm) for different treatments was measured over time for the entire duration of the experiments. Interestingly, cells supplemented with $\mathrm{NaHCO}_{3} 3 \mathrm{~g} \mathrm{~L}^{-1}$ showed a progressively significant increase in $\mathrm{Fv} / \mathrm{Fm}$ values, up to $95 \%$ higher than the control at $72 \mathrm{~h}$, indicating a strong photosynthetic performance. The increase in $\mathrm{Fv} / \mathrm{Fm}$ could indicate an increase in photosynthetic carbon fixation level and metabolic activity. In PSII, the quanta of excitation light are absorbed and transferred to reaction centers, and the whole efficiency of light trapping and energy transfer is explained by the functional absorption cross-section ( $\sigma$ PSII). In general, thylakoids of photosystems are dynamic membranes that are subjected to reorganization for the number and size of the stacks, volume of the lumen, and place of the complexes [67], based on the growing conditions or metabolic status in which the organism is located. The $\sigma$ PSII, values observed in this study, showed a sensible decrease in treatments enriched with bicarbonate. $\sigma \mathrm{PSII}$ for $\mathrm{NaHCO}_{3} 3 \mathrm{~g} \mathrm{~L}^{-1}$ was, in fact, $\sim 20 \%$ lower than the control at $72 \mathrm{~h}$, with maximum differences observed between these two cases at $4 \mathrm{~h}$, when $\sigma \mathrm{PSII} \mathrm{NaHCO}_{3} 3 \mathrm{~g} \mathrm{~L}^{-1}$ was $\sim 40 \%$ lower than the control. These results suggest that the increased photosynthetic efficiency in bicarbonate-enriched cells was accompanied by a reduction in oPSII area. Probably, the reduction in the surface of the photosystem II directly depended on the excellent photosynthetic performance that the cells from bicarbonate enriched cultures showed. The overall data emerging from this study demonstrate that in Chlorella sorokiniana, the supplementation of bicarbonate, whose accurate concentration must be considered taking into account the cell density of the culture, led to a significant immediate improvement in the cultures. These benefic and rapid dose-dependent effects on the growth, photosynthetic efficiency, and pigment contents, together with a bactericidal and bacteriostatic effect of sodium bicarbonate addition to the culture medium, indicate this salt as an excellent substitute for gaseous $\mathrm{CO}_{2}$. 


\section{Conclusions}

The use of sodium bicarbonate as a $\mathrm{Ci}$ source, in concentrations up to $3 \mathrm{~g} \mathrm{~L}^{-1}$, clearly affects both growth and photosynthetic efficiency in Chlorella sorokiniana $24 \mathrm{~h}$ after its addition. Bicarbonate administration leads to an increase in cellular size, probably related to starch or lipid accumulation, improving the photosynthetic efficiency in a linear way with the increase in the amount of bicarbonate added to the culture.

This trend was also observed in the amount of pigment per cell. Another aspect that should be taken into account is that bicarbonate addition inhibits bacterial growth, also demonstrating bacteriostatic and bactericide activity. All these results suggest that the use of bicarbonate in Chlorella culture can be a valid and alternative method to $\mathrm{CO}_{2}$ insufflation not only for intensive culture growth but also for the production of potentially bioactive compounds in a short time due to its rapid dose-dependent effect.

Supplementary Materials: The following are available online at http://www.mdpi.com/2076-3417/10/13/4515/s1, Figure S1: Pigment composition of Chlorella sorokiniana. Chromatogram in absorbance of eluted pigments, Table S1: Growth rate and doubling time in control and in sodium bicarbonate enriched cultures, Table S2. Time course of changes in pigments:chlorophyll $a$ ratio in control and in sodium bicarbonate enriched cultures.

Author Contributions: Conceptualization, G.S., S.C.; methodology, G.S., F.B., M.A., F.C.; writing—original draft preparation, G.S., S.C., F.B., O.M. All authors have read and agreed to the published version of the manuscript.

Funding: This research was carried out in the frame of Programme STAR, financially supported by UniNA and Compagnia di San Paolo (Bando STAR-2018).

Conflicts of Interest: The authors declare that the research was conducted in the absence of any commercial or financial relationships that could be construed as a potential conflict of interest.

\section{References}

1. Priyadarshani, I.; Rath, B. Commercial and industrial applications of micro algae-A review. J. Algal Biomass Utl. 2012, 3, 89-100.

2. Barros, A.I.; Gonçalves, A.L.; Simões, M.; Pires, J.C.M. Harvesting techniques applied to microalgae: A review. Renew. Sustain. Energy Rev. 2015, 41, 1489-1500. [CrossRef]

3. Carfagna, S.; Salbitani, G.; Bottone, C.; Vona, V. Galdieria sulphuraria as a Possible Source of Food Colorant. J. Nutr. Ecol. 2016, 3, 78-81. [CrossRef]

4. Vona, V.; Di Martino Rigano, V.; Andreoli, C.; Lobosco, O.; Caiazzo, M.; Martello, A.; Carfagna, S.; Salbitani, G.; Rigano, C. Comparative analysis of photosynthetic and respiratory parameters in the psychrophilic unicellular green alga Koliella antarctica, cultured in indoor and outdoor photo-bioreactors. Physiol. Mol. Biol. Plants 2018, 24, 1139-1146. [CrossRef] [PubMed]

5. Carfagna, S.; Landi, V.; Coraggio, F.; Salbitani, G.; Vona, V.; Pinto, G.; Pollio, A.; Ciniglia, C. Different characteristics of C-phycocyanin (C-PC) in two strains of the extremophilic Galdieria phlegrea. Algal. Res. 2018, 31, 406-412. [CrossRef]

6. Bottone, C.; Camerlingo, R.; Miceli, R.; Salbitani, G.; Sessa, G.; Pirozzi, G.; Carfagna, S. Antioxidant and anti-proliferative properties of extracts from heterotrophic cultures of Galdieria sulphuraria. Nat. Prod. Res. 2019, 15, 1-5. [CrossRef] [PubMed]

7. Giuliano, G.; Demurtas, O.; Ferrante, P. Le microalghe come bio-fabbriche per composti ad elevato valore aggiunto. ENEA Magazine, EAI Speciale. Biotecnologie per lo Sviluppo Sostenibile 2013, I, 61-66.

8. Serive, B.; Kaas, R.; Bérard, J.B.; Pasquet, V.; Picot, L.; Cadoret, J.P. Selection and optimisation of a method for efficient metabolites extraction from microalgae. Bioresour. Technol. 2012, 124, 311-320. [CrossRef]

9. Basu, S.; Mackey, K.R.M. Phytoplankton as Key Mediators of the Biological Carbon Pump: Their Responses to a Changing Climate. Sustainability 2018, 10, 869. [CrossRef]

10. Poschenrieder, C.; Fernandez, J.A.; Rubio, L.; Perez, L.; Teres, J.; Barcelo, J. Transport and use of bicarbonate in plants: Current knowledge and challenges ahead. Int. J. Mol. Sci. 2018, 19, 1352. [CrossRef]

11. Santamaria, L. Why are most aquatic plants widely distributed? Dispersal, clonal growth and small-scale heterogeneity in a stressful environment. Acta Oecol. 2002, 23, 137-154. [CrossRef] 
12. Hussner, A.; Mettler-Altmann, T.; Weber, A.P.M.; Sand-Jensen, K. Acclimation of photosynthesis to supersaturated $\mathrm{CO}_{2}$ in aquatic plant bicarbonate users. Freshw. Biol. 2016, 61, 1720-1732. [CrossRef]

13. Cole, J.J.; Prairie, Y.T. Dissolved $\mathrm{CO}_{2}$. In Encyclopedia of Inland Waters; Likens, G.E., Ed.; Elsevier: Oxford, UK, 2009; Volume 2, pp. 30-34.

14. Huertas, I.E.; Colman, B.; Espie, G.; Lubian, L.M. Active transport of $\mathrm{CO}_{2}$ by three species of marine microalgae. J. Phycol. 2000, 36, 314-320. [CrossRef]

15. White, D.A.; Pagarette, A.; Rooks, P.; Ali, S.T. The effect of sodium bicarbonate supplementation on growth and biochemical composition of marine microalgae cultures. J. Appl. Phycol. 2012, 25, 153-165. [CrossRef]

16. Mondal, M.; Khanra, S.; Tiwari, O.N.; Gayen, K.; Halder, G.N. Role of carbonic anhydrase on the way to biological carbon capture through microalgae-A mini review. Environ. Prog. Sustain. Energy 2016. [CrossRef]

17. Giordano, M.; Beardall, J.; Raven, J.A. $\mathrm{CO}_{2}$ concentrating mechanisms in algae: Mechanisms, environmental modulation, and evolution. Annu. Rev. Plant. Biol. 2005, 56, 99-131. [CrossRef]

18. Reinfelder, J.R. Carbon concentrating mechanisms in eukaryotic marine phytoplankton. Ann. Rev. Mar. Sci. 2011, 3, 291-315. [CrossRef]

19. Zhao, K.; Wu, Y. Effects of Zn Deficiency and Bicarbonate on the Growth and Photosynthetic Characteristics of Four Plant Species. PLoS ONE 2017, 12, e0169812. [CrossRef]

20. Acièn, F.G.; Gonz'alez, C.V.; Fern'andez, J.M.; Molina, E. Conversion of $\mathrm{CO}_{2}$ into biomass by microalgae: How realistic a contribution may it be to significant $\mathrm{CO}_{2}$ removal? Appl. Microbiol. Biotechnol. 2012, 96, 577-586. [CrossRef]

21. Nunez, M.; Quigg, A. Changes in growth and composition of the marine microalgae Phaeodactylum tricornutum and Nannochloropsis salina in response to changing sodium bicarbonate concentrations. J. Appl. Phycol. 2015, 28, 2123-2138. [CrossRef]

22. De Farias Silva, C.E.; Grisa, B.; Sforza, E.; La Rocca, N.; Bertucco, A. Effects of Sodium Bicarbonate on Biomass and Carbohydrate Production in Synechococcus PCC 7002. Chem. Eng. Trans. 2016, 49, 241-246.

23. Kim, G.Y.; Roh, K.; Han, J.I. The use of bicarbonate for microalgae cultivation and its carbon footprint analysis. Green Chem. 2019, 21, 5053-5062. [CrossRef]

24. Gardner, R.D.; Lohman, E.; Gerlach, R.; Cooksey, K.E.; Peyton, B.M. Comparison of $\mathrm{CO}_{2}$ and bicarbonate as inorganic carbon sources for triacylglycerol and starch accumulation in Chlamydomonas reinhardtii. Biotechnol. Bioeng. 2012, 110, 87-96. [CrossRef] [PubMed]

25. Pancha, I.; Chokshi, K.; Ghosh, T.; Paliwal, C.; Maurya, R.; Mishra, S. Bicarbonate supplementation enhanced biofuel production potential as well as nutritional stress mitigation in the microalgae Scenedesmus sp. CCNM 1077. Bioresour. Technol. 2015, 193, 315-323. [CrossRef] [PubMed]

26. Srinivasan, R.; Mageswari, A.; Subramanian, P.; Suganthi, C.; Chaitanyakumar, A.; Aswini, V.; Gothandam, K.M. Bicarbonate supplementation enhances growth and biochemical composition of Dunaliella salina $\mathrm{V}-101$ by reducing oxidative stress induced during macronutrient deficit conditions. Sci. Rep. 2018, 8, 1-14. [CrossRef] [PubMed]

27. Salbitani, G.; Barone, C.M.A.; Carfagna, S. Effect of bicarbonate on growth of the oleaginous microalga Botryococcus braunii. Int. J. Plant Biol. 2019, 10, 8273. [CrossRef]

28. Zhang, R.L.; Wang, J.H.; Cheng, L.Y.; Tang, Y.J.; Chi, Z.Y. Selection of microalgae strains for bicarbonate based integrated carbon capture and algal production system to produce lipid. Int. J. Green Energy 2019, 16, 825-833. [CrossRef]

29. Salbitani, G.; Del Prete, S.; Bolinesi, F.; Mangono, O.; De Luca, V.; Carginale, V.; Donald, W.A.; Supuran, C.T.; Carfagna, S.; Capasso, C. Use of an immobilized thermostable $\alpha$-CA (SspCA) for enhancing the metabolic efficiency of the freshwater green microalga Chlorella sorokiniana. J. Enzyme Inhib. Med. Chem. 2020, 35, 913-920. [CrossRef]

30. De Andrade, C.J.; De Andrade, L.M. An overview on the application of genus Chlorella in biotechnological processes. J. Adv. Res. Biotechnol. 2017, 2, 1-9. [CrossRef]

31. Sampathkumar, S.J.; Gothandam, K.M. Sodium bicarbonate augmentation enhances lutein biosynthesis in green microalgae Chlorella pyrenoidosa. Biocatal. Agric. Biotechnol. 2019, 22, 101406. [CrossRef]

32. Vadlamani, A.; Pendyala, B.; Viamajala, S.; Varanasi, S. High Productivity Cultivation of Microalgae without Concentrated $\mathrm{CO}_{2}$ Input. ACS Sustain. Chem. Eng. 2019, 7, 1933-1943. [CrossRef] 
33. Guccione, A.; Biondi, N.; Sampietro, G.; Rodolfi, L.; Bassi, N.; Tredici, M. Chlorella for protein and biofuels: From strain selection to outdoor cultivation in a Green Wall Panel photobioreactor. Biotech. Biofuels 2014, 7 , 84. [CrossRef]

34. Cazzaniga, S.; Dall'Osto, L.; Szaub, J.; Scibilia, L.; Ballottari, M.; Purton, S.; Bassi, R. Domestication of the green alga Chlorella sorokiniana: Reduction of antenna size improves light-use efficiency in a photobioreactor. Biotechnol. Biofuels 2014, 7, 157. [CrossRef] [PubMed]

35. Li, J.; Li, C.; Lan, C.Q.; Liao, D. Effects of sodium bicarbonate on cell growth, lipid accumulation, and morphology of Chlorella vulgaris. Microb. Cell Fact. 2018, 17, 111. [CrossRef] [PubMed]

36. Lohman, E.; Gardner, R.D.; Pedersen, T.; Peyton, B.M.; Cooksey, K.E.; Gerlach, R. Optimized carbon regime for enhanced growth and lipid accumulation in Chlorella vulgaris. Biotech. Biofuel 2015, 8, 82. [CrossRef]

37. Jayasankar, R.; Valsala, K.K. Influence of different concentrations of bicarbonate on growth rate and chlorophyll content of Chlorella salina. J. Mar. Biol. Assoc. India 2008, 50, 74-78.

38. Salbitani, G.; Wirtz, M.; Hell, R.; Carfagna, S. Affinity purification of O-acetylserine (thiol) lyase from Chlorella sorokiniana by recombinant proteins from Arabidopsis thaliana. Metabolites 2014, 4, 629-639. [CrossRef]

39. Holm-Hansen, O.; Lorenzen, C.J.; Holmes, R.W.; Strickland, J.D. Fluorometric determination of chlorophyll. J. Cons. Int. Explor. Mer. 1965, 30, 3-15. [CrossRef]

40. Bolinesi, F.; Arienzo, M.; Donadio, C.; Ferrara, L.; Passarelli, A.; Saggiomo, M.; Saggiomo, V.; Stanislao, C.; Trifuoggi, M.; Mangoni, O. Spatial and temporal variation of phytoplankton community structure in a coastal marine system subjected to human pressure. Reg. Stud. Mar. Sci. 2020, 35, 101198. [CrossRef]

41. Vidussi, F.; Claustre, H.; Bustillos-Guzman, J.; Cailliau, C.; Marty, J.C. Determination of chlorophylls and carotenoids of marine phytoplankton: Separation of chlorophyll $a$ from divinylchlorophyll $a$ and zeaxanthin from lutein. J. Plankton Res. 1996, 18, 2377-2382. [CrossRef]

42. Brunet, C.; Mangoni, O. Determinazione quali-quantitativa dei pigmenti fitoplanctonici mediante HPLC. In Metodologie di Studio del Plancton Marino; Socal, G., Buttino, I., Cabrini, M., Mangoni, O., Penna, A., Totti, C., Eds.; Istituto Superiore per la Protezione e la Ricerca Ambientale: Roma, Italy, 2010; Volume 56, pp. 379-385.

43. Mauzerall, D.; Greenbaum, N.L. The absolute size of a photosynthetic unit. Biochim. Biophys. Acta 1989, 974, 119-140. [CrossRef]

44. Falkowski, P.; Raven, J. Aquatic Photosynthesis, 2nd ed.; Princeton University Press: Princeton, NJ, USA, 2007; p. 448.

45. Mangoni, O.; Saggiomo, V.; Bolinesi, F.; Margiotta, F.; Budillon, G.; Cotroneo, Y.; Misic, C.; Rivaro, P.; Saggiomo, M. Phytoplankton blooms during austral summer in the Ross Sea, Antarctica: Driving factors and trophic implications. PLoS ONE 2017, 12, e0176033. [CrossRef] [PubMed]

46. Cullen, J.J.; Davis, R.F. The blank can make a big difference in oceanographic measurements. Limnol. Oceanogr. Bull. 2003, 12, 29-355. [CrossRef]

47. Maxwell, K.; Johnson, G.N. Chlorophyll fluorescence-A practical guide. J. Exp. Bot. 2000, 51, $659-668$. [CrossRef]

48. Schreiber, U.; Klughammer, C.; Kolbowski, J. Assessment of wavelength-dependent parameters of photosynthetic electron transport with a new type of multi-color PAM chlorophyll fluorometer. Photosynth. Res. 2012, 113, 127. [CrossRef]

49. International Organization for Standardization. Microbiology of Food and Animal Feeding Stuffs-General Requirements and Guidance for Microbiological Examinations-Amendment 1; ISO 7218:2007/Amd 1:2013, Corrected Version 15 April 2014; International Organization for Standardization: Geneva, Switzerland, 2014.

50. APHA; AWWA; WEF. Standard Methods for the Examination of Water and Wastewater, 20th ed.; American Public Health Association: Washington, DC, USA, 1998.

51. Schumann, F.K.; Lorenzen, C.J. Quantitative degradation of chlorophyll by a marine herbivores. Limnol. Oceanogr. 1975, 2, 580-586. [CrossRef]

52. Collos, Y.; Husseini-Ratrema, J.; Bec, B.; Vaquer, A.; Hoai, T.L.; Rougier, C.; Pons, V.; Souchu, P. Pheopigment dynamics, zooplankton grazing rates and the autumnal ammonium peak in a Mediterranean lagoon. Hydrobiologia 2005, 550, 83-93. [CrossRef]

53. Richmond, A.; Hu, Q. Handbook of Microalgal Culture: Applied Phycology and Biotechnology; Wiley Blackwell: Hoboken, NJ, USA, 2013. [CrossRef] 
54. Chi, Z.; Elloy, F.; Xie, Y.; Hu, Y.; Chen, S. Selection of microalgae and cyanobacteria strains for bicarbonate-based integrated carbon capture and algae production system. Appl. Biochem. Biotechnol. 2014, 172, 447-457. [CrossRef]

55. Russo, M.E.; Bareschino, P.; Olivieri, G.; Chirone, R.; Salatino, P.; Marzocchella, A. Modeling of slurry staged bubble column for biomimetic $\mathrm{CO}_{2}$ capture. Int. J. Greenh Gas Con. 2016, 47, 200-209. [CrossRef]

56. Peirce, S.; Perfetto, R.; Russo, M.E.; Capasso, C.; Rossi, M.; Salatino, P.; Marzocchella, A. Characterization of technical grade carbonic anhydrase as biocatalyst for $\mathrm{CO}_{2}$ capture in potassium carbonate solutions. Green Gas Sci. Technol. 2018, 8, 279-291. [CrossRef]

57. Peng, L.; Lan, C.Q.; Zhang, Z. Cultivation of Freshwater Green Alga Neochloris oleoabundans. Can. J. Chem. Eng. 2016, 94, 439-445. [CrossRef]

58. Work, V.H.; Randor Radakovits, R.; Jinkerson, R.E.; Meuser, J.E.; Elliott, L.J.; Vinyard, D.J.; Laurens, L.M.; Dismukes, G.C.; Posewitz, M.C. Increased Lipid Accumulation in the Chlamydomonas reinhardtii sta7-10 Starchless Isoamylase Mutant and Increased Carbohydrate Synthesis in Complemented Strains. Eukaryot. Cell. 2010, 9, 1251-1261. [CrossRef] [PubMed]

59. Chen, H.; Jiang, J.G. Osmotic responses of Dunaliella to the changes of salinity. J. Cell Physiol. 2009, 219, 251-258. [CrossRef]

60. Hörtensteiner, S. Chlorophyll degradation during senescence. Annu. Rev. Plant Biol. 2006, 57, 55-77. [CrossRef]

61. Borghini, F.; Colacevich, A.; Bergamino, N.; Micarelli, P.; Dattilo, A.M.; Focardi, S.; Loiselle, S. The microalgae Tetraselmis suecica in mesocosms under different light regimes. Chem. Ecol. 2009, 25, 345-357. [CrossRef]

62. Sade, N.; Rubio-Wilhelmi, M.; Umnajkitikorn, K.; Blumwald, E. Stress-induced senescence and plant tolerance to abiotic stress. J. Exp. Bot. 2018, 69, 845-853. [CrossRef]

63. Kolber, Z.; Wyman, K.D.; Falkowsky, P.G. Natural variability in photosynthetic energy conversion efficiency: A field study in the Gulf of Maine. Limnol. Oceanogr. 1990, 35, 72-79. [CrossRef]

64. Geider, R.J.; Greene, R.M.; Kolber, Z.; MacIntyre, H.L. Falkowski, P.G. Fluorescence assessment of the maximum quantum efficiency of photosynthesis in the western North Atlantic. Deep-Sea Res. 1993, 1, 1205-1224. [CrossRef]

65. Greene, R.I.M.; Kolber, Z.S.; Swift, D.G.; Tindale, N.W.; Falkowski, P.G. Physiological limitation of phytoplankton photosynthesis in the Equatorial Pacific determined from natural variability In the quantum yield of fluorescence. Limnol. Oceanogr. 1994, 39, 1061-1064. [CrossRef]

66. Sugget, D.J.; MacIntyre, H.L.; Kana, T.M.; Geider, R.J. Comparing electron transport with gas exchange: Parameterising exchange rates between alternative photosynthetic currencies for eukaryotic phytoplankton. Aquat. Microb. Ecol. 2009, 56, 147-162. [CrossRef]

67. Caffarri, S.; Tibiletti, T.; Jennings, R.C.; Santabarbara, S.A. Comparison Between Plant Photosystem I and Photosystem II Architecture and Functioning. Curr. Protein Pept. Sci. 2014, 15, 296-331. [CrossRef] [PubMed] 